УДК 371(09)(477.8)

DOI:

Леся Бодак, аспірант кафедри загальної педагогіки та дошкільної освіти Дрогобииького державного педагогічного університету імені Івана Франка

\title{
О. МАКАРУШКА ПРО ВИКОРИСТАННЯ ЗАРУБІЖНОГО ДОСВІДУ В ОСВІТНІХ ІНСТИТУЦІЯХГАЛИЧИНИ
}

У статті розкрито погляди О. Макарушки щодо використання педагогічного досвіду зарубіжних країн у різних освітніх інституціях. Акцентовано увагу на вивченні, аналізі, популяризаціі реформаторських ідей зарубіжних педагогів серед украйнського учительства, критичному осмисленні, абстрагуванні окремих ідей та впровадженні їх у різні типи освітніх інституцій Галичини. Розкрито американський і європейський досвід навчання й виховання дітей та молоді, вивчення іноземних мов, доцільності чи недоцільності вивчення латинської мови.

Ключові слова: освітні інституції, середня школа, університет, навчання, виховання, іноземна мова, О. Макарушка.

Jim. 7.

Lesya Bodak, Postgraduate Student of the General Pedagogy and Preschool Education Department Drohobych Ivan Franko State Pedagogical University

\section{O. MAKARUSHKAABOUT THE USING OF FOREIGN PEDAGOGICAL EXPERIENCE IN THE EDUCATIONAL INSTITUTIONS OF GALICIA}

The article reveals the views of $O$. Makarushka on the use of the experience of foreign countries in various educational institutions of Galicia. The characteristic feature of the Froebel system is highlighted - the joint work of adults and children, where educators encourage children, accustomed to work, help to overcome difficulties. The pedagogical effect is obvious: in the course of joint activity, such features as responsibility, independence, observation, hard work, responsibility are formed.

It is proved that $O$. Makarushka advised to use the different methods of teaching, namely the selection of interesting questions that lead to discussion. In American pedagogy, the role of work of students was identified, during which children help each other. The actual views of J. Dewey, who at the school introduced a series of practical classes, the individual stages of which reflected the historical claims and inventions of the whole of mankind. Knowledge gained in the course of practical activity became their inalienable property. Education does not only play a theoretical role, but also influences the development of practical skills, forms the social and political activity of students. When working together, students help each other, learn about the ability to forgive, and establish the friendly relations.

A comparative analysis of foreign experience, its discussion with Ukrainian teachers is carried out. O. Makarushka pays special attention to the selection of lecturers in the national universities in Denmark, the charity work of women in Germany, on the peculiarities of folk education in foreign schools, answers the question: what should be education: universal or folk. The expediency of studying the Latin language, one foreign (German) language at school, is found out.

The emphasis is placed on the study, analysis, popularization of the reformist ideas of foreign teachers among Ukrainian teachers, critical reflection, abstraction of individual ideas and their implementation into different types of educational institutions in Galicia.

Keywords: the educational institutions, a secondary school, an university, an education, upbringing, a foreign language, O. Makarushka.

П остановка проблеми. У сучасних умовах педагогічна громадськість зацікавлена вивченням педагогічного досвіду європейських країн щодо навчання та виховання підростаючих поколінь. Остап Макарушка (1867 - 1931) - один серед плеяди українських педагогів, становлення якого відбулося у складний для нашої вітчизни період. Незважаючи на несприятливі зовнішні умови, О. Макарушка відбувається як педагог із глибоким знанням власної історії, популяризацією української мови. Школу розглядав складним осередком майбутнього молоді. Багато працював над реформами середньої школи, виступив ініціатором педагогічної дискусії 1926 - 1928 рр., у якій ключовим питанням стояла зміна підходу до викладання предметів, розробка нового навчального плану.

О. Макарушка належить до національносвідомої української інтелігенції, яка вболівала за 


\section{О. МАКАРУШКА ПРО ВИКОРИСТАННЯ ЗАРУБІЖНОГО ДОСВІДУ В ОСВІТНІХ ІНСТИТУЦІЯХ ГАЛИЧИНИ}

розвиток та організацію українського шкільництва. Ціла низка проблем постала в освітній сфері Галичини у першій третині XX ст., a саме: утворення гімназій, збільшення чисельності учнів, організація та впровадження при читальнях освіти для дорослих, забезпечення усім верствам населення рівного доступу до навчання грамоти, підготовка молоді до вступу до університетів. Ці завдання вимагали планової роботи над написанням та виданням підручників, методичних рекомендацій, інструкцій, вивчення зарубіжного педагогічного досвіду.

Аналіз останніх досліджень і публікацій. В історико-педагогічній науці сьогодні обмаль публікацій, які висвітлюють різнобічну діяльність Остапа Макарушки - педагога, громадського, культурно-освітнього життя Галичини кінця XIX - початку XXI ст. У публікаціях Н. Данилюк, Т. Завгородньої, Т. Б. Ступарика, М. Чепіль фрагментарно представлено окремі аспекти його педагогічної діяльності. Аналіз праць О. Макарушки засвідчує, що він сам вивчав і закликав педагогічну громадськість краю вивчати, аналізувати, пропагувати відповідно до національних умов зарубіжний досвід. У його творчому доробку особливості, аналіз дидактично-методичних характеристик іноземного досліду, зокрема, американського, данського, німецького тощо. Однак досі немає окремого дослідження, присвяченого педагогічним ідеям О. Макарушки, вивчення та використання ним зарубіжного педагогічного досвіду.

Мета статті - розкрити погляди Остапа Макарушки (1867 - 1931) щодо використання педагогічного досвіду зарубіжних країн у різних освітніх інституціях Галичини.

Виклад основного матеріалу. О. Макарушка був добре обізнананий із зарубіжним досвідом, а саме з системою організації дитячих садків Ф. Фребелем (у Галичині ї називали “фребелівки”). Характерною особливістю фребелівської системи є спільна робота дорослих та дітей, де вихователі заохочують дітей, привчають до праці, допомагають долати труднощі. Дорослі та діти виготовляють разом речі та іграшки, доглядають за тваринами, працюють на квітнику. Педагогічний ефект очевидний: при спільній діяльності формуються такі риси, як відповідальність, самостійність, спостережливість, працелюбність, відповідальність. Використовувані у дитячих городах готові матеріали до будови, зокрема, скриньки 3 камінцями до складання Ріхтера, відійшли у минуле. Діти найчастіше працюють 3 власними виробами, витворами власних рук, люблять i цінують. Готові іграшки, забавки швидко втрачають інтерес серед дітей. Під час діяльності дитина самостійно творить, і тим способом непомітно, але легко, бо майже бавлячись, розвиває свою індивідуальність (особистість) $[6,33]$.

О. Макарушка був глибоко ознайомлений із зарубіжним досвідом реформування школи. Педагог добре знав німецьку та французьку мови. Упродовж 1902/1903 н. р. перебував на стажуванні у Віденському та Берлінському університетах. Він вивчав, аналізував, пропагував погляди й реформаторські ідеї зарубіжних педагогів серед українського учительства, закликав критично їх осмислити, абстрагувати окремі ідеї, впровадити в освітню практику.

Позитивні тенденції американського досвіду описані у статті “Творча школа”. У розвідці міститься опис творчої майстерні теоретика, філософа-прагматика Джона Дьюї, який очолював педагогічний інститут в університеті Чикаго упродовж 1896 - 1904 рр. Професор О. Макарушка зауважує, що важливе місце в американській педагогіці посідає праця учнів, під час якої діти допомагають одне одному. Спільна праця виховує в учнів такі риси майбутнього характеру, як самостійність, відповідальність, спонукає до взаємодопомоги, допомагає згодом долучитися до суспільно корисної праці. Дж. Дьюї у школі запровадив низку практичних занять, які становили основу навчання: діти ткали, пряли, шили, варили і при цьому вивчали наукові основи того чи того предмета, проводили досліди, 3'ясовували причини різних процесів. Дж. Дьюї спеціально так підбирав заняття, що їх окремі етапи віддзеркалювали історичні домагання і винаходи цілого людства. Знання,до якого діти доходили такою дорогою практичної діяльності, ставало їх невід'ємною власністю [7, 3].

Завдання вчителя полягало у тому, щоб учень активно працював,досліджував, прикладав чимало зусиль. Часто вчителі допускають помилки, відводячи учневі роль спостерігача чи слухача. 3 цього приводу О. Макарушка радив використовувати різні методи навчання, а саме підбір цікавих питань, що спонукають до дискусії. Їм не відповідає навіть метод сократівського діалогу, бо при ньому учень тільки порізно щось винаходить, але насправді - керований учителем. Тому, на думку педагога, іiі доцільно замінити методом евристичної бесіди, сутність якого полягає у діалогічному методі творчої взаємодії вчителя та учнів, що базується на розв'язанні проблемної задачі за допомогою основних і навідних запитань пошукового характеру для активізації учнів самостійного пошуку істини. 


\section{О. МАКАРУШКА ПРО ВИКОРИСТАННЯ ЗАРУБІЖНОГО ДОСВІДУ В ОСВІТНІХ ІНСТИТУЦІЯХ ГАЛИЧИНИ}

Для досягнення мети учень наоснові відповідного матеріалу сам шукає шляхи подолання труднощів, а учитель обмежується спонуканням і збудженням його зацікавленості $[7,3]$. Навчання виконує не тільки теоретичну роль, а й впливає на розвиток практичних домагань учнів, формує суспільну та політичну активність. При спільній праці учні допомагають одне одному, вчаться пробачати, між ними налагоджуються дружні стосунки.

Українській школі,відзначає О. Макарушка, варто змінити підходи та сутність самого трактування понять “покарання” та “заохочення”, які $є$ застарілими і не відповідають психологічним особливостям учнів. Адже не кожне покарання спонукає дитину до кращого виконання завдання вчителя. Педагог на сторінках "Рідної школи" закликає педагогічну громадськість бути у свої повсякденній праці далекоглядними, розуміти наслідки власної діяльності, вивчати закордонний досвід. Праця була не тільки практичним пізнанням, але й підготовкою до діяльної участі в суспільномужитті: діти при спільній чинній праці ділилися своїми спостереженнями, дораджували собі і допомагали, та зживалися з собою при спільній діяльності. Тільки у спільній праці можуть виокремитися в чинну енергію вроджені дітям задатки: суспільні, творчі, дослідні та артистично-експресійні. Якщо навчальний план долучиться до цього, то тоді непотрібні покарання та заохочення [7, 4].

На початку XX ст. учителі здебільшого діяли шаблонно, одноманітно, використовуючи авторитарні методи навчання. Професор О. Макарушка вбачає головне завдання вчителя у стимулюванні самостійності учнів, формуванні вмінь пошукової творчої роботи. Розум учня, де учитель вчить, а учень слухає, привикає до послуху і залежності, а там, де учитель $є$ тільки дискретним керманичем творчої праці, ніщо не завадить самостійності учня $[7,4]$.

О. Макарушка акцентує увагу на тому, що у минуле повинні відійти такі чинники: як підручник, головне завдання якого опрацювання у книжці матеріалу, і вчитель, як центральна особистість,навколо якого і розгортаються події у школі. У новій реформованій школі на перший план має виходити особистість учня, його індивідуальні риси та потреби, робота з метою розвитку його здібностей. Педагог із гіркотою констатує: у старій школі осередок тяжкості знаходився чи в учителю, чи в підручнику, але поза дитиною. Американський досвід треба вивчати, обговорювати, абстрагувати окремі елементи, усвідомлювати необхідність використання нових ідей на практиці. Все таки треба визнати, що ідея “школи праці” вже перед війною оживила реформаторський рух і скріплює його ще більше після війни. Ідея школи праці грунтується на засаді самостійності, самочинності учня. Школа зреформована розумно, на таких засадах, за переконанням О. Макарушки, буде справді творчою школою $[7,4]$.

Рекомендуючи вчителям перейняти досвід Німеччини щодо навчання в початковій школі, О. Макарушка зауважував, що впровадження нових методик вимагає роз'яснювальної роботи, під час яких слід врахувати різні чинники, що впливають на навчання і виховання у початковій школі. Новий напрям у початковому навчанні, котрий проявив себе в Німеччині, і має багато прихильників у Свропі, зокрема, щодо поєднання навчання із забавою і легкою працею,вимагає від дітей багато невимушеного і нетомлячого руху, викликає зацікавлення, не втомлює, прив'язує відірвані поняття до конкретних, розвиває самостійність, самопорадність, збуджує розум i замилування красою. А це $є$ так звана “школа праці” $[6,23]$.

О. Макарушка описував науково-практичний досвід не тільки середніх навчальних закладів,але й вищої школи за кордоном. Особливо вразили дослідника народні університети Скандинавських країн. У статті “Вселюдні університети в Данії' описаний приклад університету Грундтвіга. В основі скандинавського досвіду цікавим було виховання сільської молоді, яка після закінчення сільської школи йде до рільничої або ремісничої праці, i, потонувши у ній, не має можливості вступити в університет. Згідно із положенням Грундтвіга, народні університети не мають навчальної програми, а на дворічних курсах ознайомлюють студентів із основними відомостями про історію, природу, фізику, літературу.

Обговорюючи зарубіжний досвід із українським учительством, О. Макарушка особливу увагу звертає на добір викладачів у народні університети в Данії. Ними можуть бути особи із суто індивідуальним характером, що вміють впливати на почуття молоді; допускається тільки усний виклад предметів, читати викладачам не можна. Університети мають заслужену популярність серед сільського населення. Мрією хлопців і дівчат є заощадити собі гроші для навчання на курсах. У Данії кожен третій мешканець села $є$ їх вихованцем $[3,11]$.

Серед зарубіжних країн, досвід яких варто вивчати та впроваджувати в українські вчительські семінарії, О. Макарушка називає Німеччину. Добре володіючи німецькою мовою, 


\section{О. МАКАРУШКА ПРО ВИКОРИСТАННЯ ЗАРУБІЖНОГО ДОСВІДУ В ОСВІТНІХ ІНСТИТУЦІЯХ ГАЛИЧИНИ}

він часто відвідував цю країну, де спостерігав за навчальним процесом. Особливо педагога вразила організація навчання жінок, що він і описує у статті “Вихованє хлопця а дівчини” [2]. Найкращими успіхами може потішитися жінка культурних народів у галузі доброчинної діяльності. Яскравим є приклад діяльності одного 3 доброчинних товариств у Німеччині, яка охоплює такі напрями:

- виховання бездоглядних дітей, які перебувають відповідно до закону на публічному вихованні;

- виховання дітей з особливими потребами, які 3 певних причин нездатні для домашнього та шкільного виховання;

- народно-педагогічна діяльність освічених жінок у сільській місцевості, зокрема на фабриках, 3 метою посередництва між роботодавцями i робітниками для працевлаштування i для особистої опіки над працюючими;

- плекання здібних і характерних для громадської діяльності учителів-жінок, вихователів і господинь для виховних установ, сиротинців тощо;

- планове облагородження товариського життя у клубах, готелях та ін. через високодуховних і високоморальних жінок, професійних опікунів;

- опіка над убогими, ув'язненими, проведення планової благочинної діяльності;

- піклування (порятунок) про морально занедбаних дівчат через спільну виховну, але не примусову працю;

- догляд немічних жінок, опіка над божевільними у закладах і сім' і;

- доброчинна опіка за кордоном над німецькими земляками, так звана опіка на чужині [2, 1918, 22].

Вивчаючи зарубіжний досвід, О. Макарушка звертав увагу на особливості народного виховання в іноземних школах, шукав відповіді на запитання: яким має бути виховання: загальнолюдським чи народним? На його думку, правильно зробили японці: загальнолюдське навчання, виховання пристосоване до народних потреб, пропущене крізь народний фільтр, що дало їм змогу упродовж кілька десятків років наблизитися до європейської цивілізації [2, 1916, 14].

Зарубіжний досвід О. Макарушка вивчав, аналізував, закликав критично осмислити та намагався впровадити у практичну педагогічну діяльність. На сторінках преси він співвідносив передові зарубіжні ідеї та результати їх впровадження. Педагог добре розумів, що нововведення можуть наштовхнутись на опір як учителів, так і влади. О. Макарушка продовжував працювати на педагогічній ниві,розподіляючи навчальний процес на етапи, накреслював нові перспективи розвитку галицького шкільництва.

У своїх педагогічних розвідках О. Макарушка часто опирається на педагогічні ідеї Жан-Жака Руссо. Особливо актуальним $\epsilon$ розвиток фізичного здоров’я дитини, “бо тільки в здоровім тілі - здорова душа” [6, 21].

Педагог розкриває також негативний досвід впровадження освітніх нововведень у Центральній частині України із приходом до влади більшовиків. У Росії уряд залишив гімназії й університети, а українців зуміли переконати, що їм не потрібно середньої школи та університетів. Через декілька років українці зрозуміли помилку, що спонукало їх до вивчення класичних мов, щоб мати змогу навчатись у Свропі $[1,8]$.

Серед тогочасного вчительського складу активно обговорювались питання вивчення мов, доцільності чи недоцільності вивчення латинської мови, яким мовам надати перевагу, з якого класу розпочинати вивчення іноземної мови, коли запровадити у навчальний процес другу іноземну мову. Основний аргумент викладання латинської мови із навчального процесу зводився до інтенсивного розвитку машинного виробництва, де значно зросла роль працівників технічних професій, гуманітарії відходили на другий план. О. Макарушка був впевнений, що “століття потрясінь і переворотів, електрики й пари” доведеться пережити, проте нікуди не зникне мудрість, дарована грецькими та римським мислителями. Тільки ті довгі безповоротні часи могли видати людству таких велетнів думки, як Сократ, Платон і Аристотель. Вони залишили нам пребагату скарбницю людської думки, а зрікатися нам тієї скарбниці - це “дитяча легкодушність!” $[1,8]$.

Латинська мова, яка у середньовіччі була основною, на початку XX ст. поступово почала втрачати позиції, все частіше й лунали голоси, що це мертва мова i не має реального застосування, окрім медичної галузі. О. Макарушка відстоював свій погляд щодо викладання латинської мови: латина ніяк органічно не пов' язана з іншими гуманістичними предметами, наука тому і створила непотрібну, штучну причіпку до них. Сеж мова мертва, якої навчання мусить відбутися чисто з граматичною метою, а не контроверсійно, що їі нині вживаємо при вивчені новітніх мов [5, 14]. Науковець противникам вивчення латинської мови нагадує: “тяжко, а часто й зовсім неможливо замінити латинську термінологію рідною - сьому приміром не тільки богословські науки, які й досі подаються найуспішніше на латині, а наукова термінології 


\section{О. МАКАРУШКА ПРО ВИКОРИСТАННЯ ЗАРУБІЖНОГО ДОСВІДУ В ОСВІТНІХ ІНСТИТУЦІЯХ ГАЛИЧИНИ}

інших галузей знання, як зоології, ботаніки, фізики, хімії, медицини й географії, не кажуть вже про так звані духовні науки, як філософія, психологія, логіка й історія" [4,28]. Цінність латинської літератури не переоцінюємо, вона $\epsilon$ справді тільки слабким відблиском грецької літератури як поезіі, так і науки. Тому для пізнання сили й краси класичного слова, думки, треба попри латину читати в гімназії добрі переклади грецьких авторів $[5,15]$.

На думку О. Макарушки, з новітніх мов треба навчати в гімназії тільки однієї мови - німецької. Німецька література є дуже багатою, має власні твори, наукові праці, переклади всіх цінніших творів всесвітньої літератури. Кожній освіченій людині достатньо знання однієї новітньої мови. Хто для наукових студій відчуватиме потребу вивчення другої європейської мови, той легко зможе це зробити протягом кількох місяців, пізнавши в гімназії методу навчання мови, а як буде мати можливість поїхати у чужу країну, так там майже без труду присвоїть собі й розмовну мову [5,15].

Висновки. Педагогічна спадшина О. Макарушки свідчить про необхідність вивчення і використання досвіду зарубіжних країн. Доцільним $\epsilon$ використання фребелівської системи у дошкільній освіті, зокрема, - спільна робота дорослих та дітей, де вихователі заохочують дітей, привчають до праці, допомагають долати труднощі. Педагогічний ефект очевидний: при спільній діяльності формуються такі риси, як відповідальність, самостійність, спостережливість, працелюбність, відповідальність. О. Макарушка радив використовувати різні методи навчання, а саме підбір цікавих питань, що спонукають до дискусії. В американській педагогіці виокремив роль праці учнів, під час якої діти допомагають одне одному. Актуальними є погляди Дж. Дьюї, який у школі запровадив низку практичних занять, окремі етапи яких віддзеркалювали історичні домагання і винаходи цілого людства. Знання, отримані у процесі практичної діяльності, ставали їх невід'ємною власністю. Навчання виконує не тільки теоретичну роль, а й впливає на розвиток практичних навичок, формує суспільну та політичну активність учнів. Порівняльний аналіз зарубіжного досвіду, його обговорення з українським учительством дав змогу О. Макарушці особливу увагу звернути на добір викладачів у народні університети в Данії, доброчинній діяльності жінок у Німеччині, на особливості народного виховання в іноземних школах тощо. На його думку, доцільним $є$ вивчення латинської мови, однієї іноземної (німецької) мови у школі, аналіз, популяризація реформаторських ідеї зарубіжних педагогів серед українського учительства, критичне осмислення, абстрагування окремих ідеї та впровадженні їх у різні типи освітніх інституцій.

Подальшого вивчення потребують теоретикометодологічні та методичні основи підготовки педагогів до виховної роботи, форми й методи громадянського виховання учнів у різних типах навчально-виховних закладів.

\section{ЛІТЕРАТУРА}

1. Макарушка О. В справі гімназій "Рідної школи" / О. Макарушка // Рідна Школа. - 1927. Рік І. - Ч. 4. C. $8-9$.

2. Макарушка О. Вихованє хлопця а дївчини / O. Макарушка // Наша школа. - 1916. Р. VII. - Зш. 2 - 3. - С. 14 - 16; 1918. Рік IX. - Зш. 1-2. - С. 2 - 28.

3. Макарушка О. Вселюдні університети в Данії / О. Макарушка // Рідна Школа. - 1927. Рік І. - Ч. 4. C. $1-11$.

4. Макарушка О. Грека й латина, чи новітні мови / О. Макарушка // Поступ. - 1921. -Р. І. - Ч. 2-3. - С. 27 -33 .

5. Макарушка О. До реформи середньої школи / О. Макарушка // Українська школа. - 1930. Рік XV. Ч. 3 i 4 . - C. 15 .

6. Макарушка О. Наука виховання: підручник [для шкіл і родин]/ О. Макарушка. - Львів: Друк. Наукового Товариства ім. Шевченка, 1922. - 155 с.

7. Макарушка О. Творча школа / О. Макарушка // Рідна Школа. - 1927. Рік1. Ч 1. С. 3 - 4.

\section{REFERENCES}

1. Makarushka, O. (1927). Vspravi himnazii "Ridnoi shkoly" [In the case of Gymnasium "Native school"]. Native School, part 4, pp. 8-9. [in Ukrainian].

2. Makarushka, O. (1916). Vykhovanie khloptsia a divchyny [Boy and girl education]. Our School, R. VII, Zsh. 2-3, pp. $14-16$; 1918, Zsh. 1-2, pp. 2 - 28. [in Ukrainian].

3. Makarushka, O. (1927). Vseliudni universytety $v$ Danii [Universities in Denmark]. Native School, part 4, pp. 1 - 11. [in Ukrainian].

4. Makarushka, O. (1921). Hreka i latyna, chy novitni movy [Greek and Latin, or the newest languages]. Postup, R. I, part. 2-3, pp. 27 -33. [in Ukrainian].

5. Makarushka, O. (1930). Do reformy serednoi shkoly [To reform of the secondary school]. Ukrainian school, part 3; 4, p. 15. [in Ukrainian].

6. Makarushka, O. (1922). Nauka vykhovannia: pidruchnyk dlia shkil i rodyn [Science education: textbook for schools and families]. Lviv: Druk. Naukovoho Tovarystva im. Shevchenka, 155 p. [in Ukrainian].

7. Makarushka, O. (1927). Tvorcha shkola [Creative school]. Native School, part 1, pp. 3 - 4. [in Ukrainian].

Стаття надійшла до редакції 27.02.2018 